\begin{tabular}{|c|c|c|}
\hline \multicolumn{2}{|r|}{ JSM (10) (2) } & \\
\hline (2) & JURNAL SENI MUSIK & \\
\hline & https://journal.unnes.ac.id/sju/index.php/jsm/index & \\
\hline
\end{tabular}

\title{
Learning Method Of Gita Buana Soedirman's Choir Of Jendral Soedirman University Purwokerto
}

\author{
Dea Fitri Ardi ${ }^{\bowtie 1}$ \\ Universitas Negeri Semarang Indonesia \\ Eko Raharjo
}

Universitas Negeri Semarang, Indonesia

\begin{tabular}{|c|c|}
\hline Article Info & Abstract \\
\hline $\begin{array}{l}\text { Submitted : August, } 2021 \\
\text { Revised : November,2021 } \\
\text { Accepted:December,2021 }\end{array}$ & $\begin{array}{l}\text { Learning methods are ways of presenting subject matter conducted by educators so that the learning } \\
\text { process occurs in students in an effort to achieve goals. The problem in this research is how is the } \\
\text { method of learning students' choir Gita Buana Soedirman Purwokerto. This research used the } \\
\text { descriptive qualitative method. Data collection is conducted by using observation, interview, and } \\
\text { documentation techniques. The data validity technique used is triangulation. Data analysis was } \\
\text { conducted in data reduction, data presentation, drawing conclusions, and verification. The results }\end{array}$ \\
\hline $\begin{array}{l}\text { Keywords: } \\
\text { Learning Method, } \\
\text { Student Choir }\end{array}$ & $\begin{array}{l}\text { of this study are that in the learning process of the Gita Buana Soedirman Choir's students apply } \\
\text { several learning methods, that are the lecture method, peer tutor method, demonstration method, } \\
\text { drill method, and imitation method which are applied continuously and as it should be. }\end{array}$ \\
\hline
\end{tabular}




\section{INTRODUCTION}

Music is a sound received by individuals and varies based on the history, location, culture and tastes of the individual (Halimah, 2016). Simanungkalit also revealed that music is the beauty of audible sounds. This sound is originally based on two sources, produced by tools and produced by humans. The sounds produced by the tools are called instrumentals and the sounds produced by humans are called vowels. (Simanungkalit, 2008).

Vowels can also be said to be instruments, as vowels are sounds produced by human vocal cords (Mudjilah, 2010). According to Simanungkalit vocal music is music that is sourced from a human voice, can be sung by a singer or a group of people. If sung individually called solo, and if sung simultaneously called a together voice (samen zinger). This together voice when sung with harmony and various colors of sound (timbre) such as soprano, alto, tenor, and bass, is called choir music". (Simanungkalit, 2008).

"Choir is a term that refers to an ensemble consisting of singers and music performed by the ensemble. A choir is a joint singing in several voices performed by 8 or more people" (Jamalus, 1976:74). Choirs are usually led by a conductor or choirmaster who is generally at once the choir coach. Generally, a choir consists of four parts of the sound (e.g. soprano, alto, tenor, and bass), although it can be said that there is no limit to the number of sounds contained in the choir. In addition to the four sounds, the most prevalent number of sound types in a choir are three, five, six and eight. When singing with one voice, the choir is termed as unison singing (Sihombing, 2017).

Choir activities in Indonesia have grown very rapidly in recent years. This is due to the increased interest in singing in society, teacher resources, and easy access to choral songs, both from inside the country and abroad. This development made the interest of the society and the activator of the choir art competing to be the best at leading the trained choirs. In addition, the organizing of choir festivals/competitions, both national and international scale also began to be widely held, among others, like church choir feast or Pesta Paduan Suara Gerejawi (PESPARAWI), Bali International Choral, Medan International Choral (Pranoto, 2020).

The development of the choir is very fast among the society, especially in urban areas (Juwariyah, 2018). Purwokerto is a city of Banyumas Regency (Kabupaten Banyumas) that is growing rapidly in the field of arts, especially music (I. A. Purnomo, 2013). In Purwokerto City, there are many choir groups, one of the groups is Gita Buana Soedirman Choir which is located in Purwokerto City. Gita Buana Soedirman Student Choir is one of the Student Activity Units or Unit Kegiatan Mahasiswa (UKM) at Jendral Soedirman Purwokerto University. Gita Buana Soedirman Student Choir has many achievements in the national and international arena, among others: 1) Bali International Choral Festival 2015 won two gold medals. 2) Singapore International Choral Festival 2015 won silver medal and gold medal. 3) The $6^{\text {th }} 2017$ Thai Grand Prix won one gold medal, one silver medal, and the Top Three Absolute Winner. 4) Bali International Choral Festival 2019 received gold medal and silver medal in mix category. 5) Taipei International Choral Competition 2019 won the silver award in mixed choir and gold award in ethnic/traditional music category.

The previous research on choir learning methods has been researched by Renita Anjar Sari in Sendratasik Journal 5 (1) with the title "Choir Training Methods at Spensix Choir SMP Negeri 6 Surabaya." The results of this study are in the process of choir training SMP Negeri 6 Surabaya choir coaches apply 3 continuous training methods, namely: linear methods, imitation methods, and fluctuating methods.

Based on the background of the Gita Buana Soedirman Student Choir, the author is interested in the story behind the glorious achievements achieved by the Gita Buana Soedirman Student Choir. The role of applying vocal techniques through training methods is assumed to have a great 
contribution to the accomplishments achieved. This phenomenon is interesting to research, especially about the training methods applied by the Gita Buana Soedirman Student Choir.

\section{METHOD}

This research uses qualitative descriptive methods. The essence of qualitative research is observing people in their living environment interacting with them, trying to understand the language and interpretation of the world around them, come up or interacting with people who are related to the focus of research with the aim of trying to understand, explore their views and experiences to get the necessary information or data (Iskandar, 2009: 11). Qualitative descriptive research is research that intends to understand phenomena about what is the thing experienced by the subject of research, e.g. behavior, perception, motivation, action, etc., holistically and by the method of description in the form of words and language, in a special context that is natural and by utilizing various natural methods (Moleong, 2007: 6). The researchers use qualitative descriptive research types because they want to describe the student choir learning method and describe the analysis result of the learning methods used. This research was conducted at UKM Student Choir Gita Buana Soedirman, Jenderal Soedirman Purwokerto University which is located on J1. Prof. Dr. HR. Boenyamin No. 708, Dukuhbandong, Grendeng, Kecamatan Purwokerto Utara, Kabupaten Banyumas. The target of the study was a choir coach. The object taken as the data in the study was a sample of the song along with the notation used in the exercise process.

The data collection techniques used in this study are methods of observation, interview, and documentation. The data validity technique used is triangulation. While in data analysis techniques, there are three activities carried out, that are data reduction, data presentation, and drawing conclusion and verification.

\section{RESULTS AND DISCUSSIONS}

Gita Buana Soedirman Choir has been around since the 60's since Jendral Soedirman University was established. According to the explanation of John Markus Pardede, the coach of the Gita Student Choir Buana Soedirman UKM PSM GBS in the 60's already exists but does not establish officially, only in the form of a students' community who like to sing. Then entered the year 2000, this community began to be officially established under the name Choir Unit or Unit Paduan Suara (UPS). Later at the Member's Discussion or Musayawarah Anggota (MUSANG) in 2000, the Choir Unit (UPS) changed to Gita Buana Soedirman Choir. Gita Buana Soedirman Choir underwent another name change at the $19^{\text {th }}$ Member's Conference (MUSANG) renamed the Gita Buana Soedirman Student Choir (PSM GBS) until now.

The choir learning process at UKM Student Choir Gita Buana Soedirman is led by John Markus Pardede. He is the coach of UKM Student Choir Gita Buana Soedirman who is also an alumnus of UKM Student Choir Gita Buana Soedirman. He in addition to serving as a coach also served as a conductor when UKM Student Choir performed both competitions and concerts held by UKM Student Choir Gita Buana Soedirman. In addition, when the coach is absent, the exercise will still be held and led by the UKM manager of the Gita Student Choir Buana Soedirman from the Gita field. Gita field itself is one of the fields in the management of UKM Gita Buana Soedirman Student Choir which is responsible for the training process both to lead the exercise and to distribute the song partiture to be learned to the members of UKM Gita Buana Soedirman Student Choir (interview with Indra Wijaya as the Chairman of UKM Choir).

Choir learning in the Gita Buana Soedirman Student Choir is divided into two, namely routine training and competition training. Both routine training and competition training have the same sequence of exercises, which differ only in the song material and also the members who join the exercise. The concatenation of the training process of The Gita Buana Soedirman Student 
Choir is as follows: the opening containing a prayer together, vocalization exercises (breath training, hiss, staccato, legato, humming, lip trill, trill tongue) harmonization exercises, hearing exercises, and song exercises (interview with Indra Wijaya as Chairman of UKM Student Choir Gita Buana Soedirman, November $9^{\text {th }}, 2019$ ).

The training materials of UKM Student Choir Gita Buana Soedirman are as follows:

a) Breath Training

Respiration consists of inspiration, in which air passes through the glottis, trachea of the throat, and bronchial tubes to enter the lungs and expiration where the air is exhaled back through the same duct (Marchesi \&Miller, 1970). This exercise aims to train the respiratory organs that will be used when singing. This exercise is done by breathing through the nose, then held in the diaphragm cavity, and exhaled, and so on 4-5 times, this exercise usually takes about 2 minutes.

b) Hiss Training

This exercise is the same as breathing exercises, it's just that when exhaling through the mouth with the position of the upper and lower teeth tightly while the position of the lips is slightly opened so that when the breath is released causes hiss due to the air released passes through the sidelines of the teeth. The purpose of this exercise is to train the respiratory organs used when singing. The duration of the hissing exercise is about 2 minutes.

c) Staccato Training

Staccato is singing in a discontinuous way, most easily formed on the head voice, so that the exercises should be with high tones (Linggono, 2008).

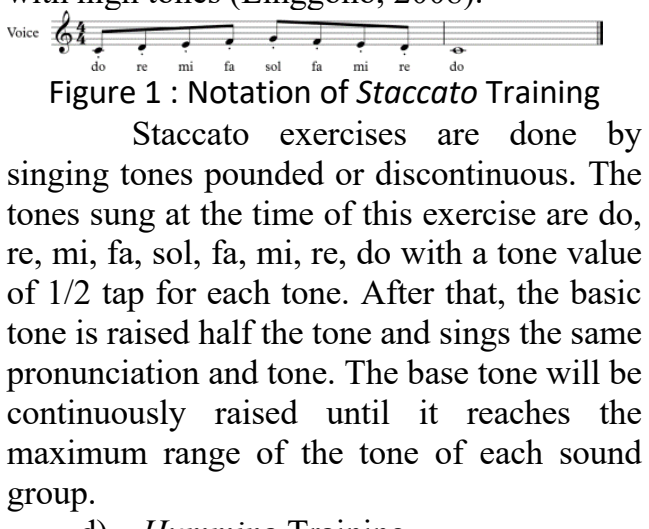

d) Humming Training
Humming is humming without opening the mouth, in the warm-up here humming is done by humming "hmm". In its variations humming is conducted with certain tones according to what the coach needs (Akhsin, 2013). The humming exercise is done by singing a tone from a low 'do' to a high 'do' for each 4 taps note. Later, the tone scale is raised by half the tone until it reaches the maximum sound range of each sound group. The purpose of this exercise is to warm up the vocal cords and also warm up the organs used in singing. The duration of this exercise is about 5 minutes.

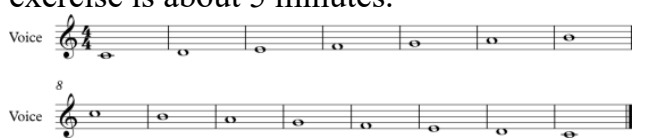

Figure 2 : Notation of Humming Training

e) Legato Training

Legato is singing a song in a spliced way (Purnomo \& Subagyo, 2010). Legato training is conducted by singing a tone with the pronunciation "yohana". This exercise aims to train long tones and train the tone moves that are usually found in songs. This exercise is done by singing the tone of do, sol, $\mathrm{fa}, \mathrm{mi}$, re, do with the pronunciation "yohana". Afterward, the basic tone is raised $1 / 2$ of the tone continuously until it reaches the maximum range of tones that can be sung by each group of sounds.

Figure $3:$ Notation of Legato Training
f) Tongue Trill
Tongue trill is a useful vocal warming tool and can be safely voiced throughout the singer's range. As in other vocal effects, always obey the range of normal singing vocals when applying trill to a warmup or song. Never bring a chest voice higher than its comfortable range (Mabry, 2003). Tongue trill exercises are done by singing tones do, re, mi, fa, sol, fa, mi, re, do with pronunciation ru, ra, ri, ra, ru, ra, ri, ra, ru. This pronunciation causes the tongue to trill when reciting it. This exercise intends so that when singing the song, the choir members can sing the lyrics clearly. This exercise starts from one tones' scale which then rises $1 / 2$ of the tone continuously until it reaches the maximum range of tones that can be sung by each group of sounds. Based on the results of an interview with Indra Wijaya as the chairman of the Gita 
Buana Soedirman Student Choir on November 1, 2019, the duration of this exercise is about 5 minutes.

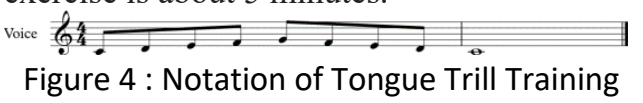

g) Lip Trill

Lip trill is one of the vocal exercises wherein this exercise aims to flex the lips so as not too stiff when singing. Using lip trill (motorboat) is also a useful tool for bringing tones forward and creating movement ("spin") in sound. Start with lip vibration, immediately jumping to the selected vocals in a given tone to push the tone forward (Skoog, 2004). This exercise is carried out with the mouth closed position then both lips are vibrated while singing the tone of do, re, mi, fa, sol, fa, mi, re, do. It is then raised to $1 / 2$ tone on a continuously different tone scale until it reaches the maximum range of tones that each group of voices can sing. The duration of this exercise is about 3 minutes.

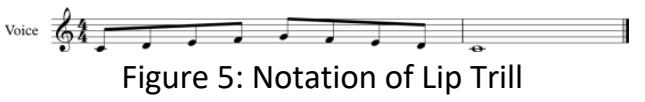

h) Harmonization

The choir is identical to the art of processing vocals. Good vocal processing in a choir there are 2 (two) important elements that need to be noticed, they are technical and nontechnical elements. Technical elements include techniques in singing melody, harmony, and rhythm, while non-technical elements in the choir are more emphasis on an aesthetic which includes taste, dynamics, tempo, and interpretation (Pamungkas, 2016). Science of harmony is a music knowledge that discusses and talks about the beauty of musical composition (Banu in Yonathan, 2013).

Harmonization training is an exercise that is done with the aim that each group of sounds can blend together so as to produce beautiful harmony when heard. This exercise is done by breaking the chords into several sounds so that it becomes harmony. In this exercise, the choir members sing the tone according to the group of voices. Then the tone's scale raised $1 / 2$ tone continuously until it reaches the maximum range of sound that can be sung by each group of sounds. The duration of this exercise is about 5 minutes.

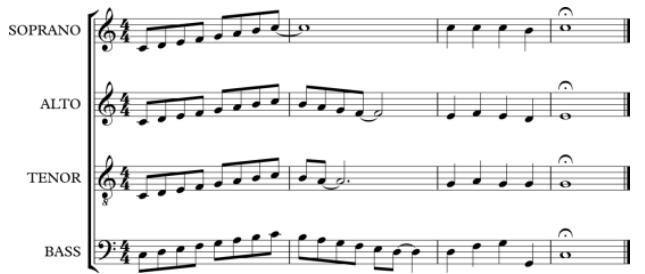

Figure 6 : Notation of Harmonization Training

i) Hearing Training

Hearing training is an exercise that requires each member of the choir to be sensitive to tone. In this exercise, the coach will give the main melody or cantus firmus which is sung to the soprano, and then the other group of voices officiates to find the split of his own voice so that it can produce harmony. The duration of this exercise is about 5 minutes.

\section{j) Song Training}

The song rehearsal is an exercise in a series of rehearsals at the Gita Buana Soedirman Student Choir. Song rehearsals are performed in a combined entire sound group. The song used in the exercise is usually the song that will be performed during the competition.

Learning methods used in the training process of Gita Buana Student Choir Soedirman Purwokerto include:

1) Lecture Method

This method is used in the learning of the Gita Buana Soedirman Student Choir as an introduction when going into the training process. In the learning process of the Gita Buana Soedirman Student Choir, the application of the lecture method is not too much because this method only functionates as an introduction. The application of this method by Gita Buana Soedirman Student Choir's coach is applied when learning a new song then the coach will use the lecture method to explain the musical and nonmusical elements of a song. Like the example of the song Sik Sik Sibatumanikam arrangement from Tommyanto Kandisapura. Gita Buana Soedirman Student Choir's coach will explain first to the members of the Gita Buana Soedirman Student Choir about the musical and non-musical elements of the song through lecture methods.

Musical elements of a song such as a birama sign, tempo, timbre, or sound color. For example, a song that has been trained by 
the Gita Buana Soedirman Student Choir is the song Sik Sik Sibatumanikam arranged by Tommyanto Kandisapura. In learning the song Sik Sik Batumanikam, the coach firstly explained through a lecture method about the musical elements of the song. The coach explained that the song Sik Sik Batumanikam has a birama $4 / 4$, the tempo of the song is allegro or sung with a fast tempo, timbre, or SATB sound color with the distribution of soprano, alto, tenor, bass.

Non-musical elements such as the history of the song, the meaning of the song, and the origin of the song. Like the example in the regional song Sik Sik Sibatumanikam, the coach explained that the song came from Kabupaten Tapanuli Utara, North Sumatra. The song was created by NN (No Name). This song was presented in unison, then by Tommyanto Kandisapura was composed into a choir song with the division of soprano, Alto, Tenor, Bass. Using Batak language, this song is a song that is used as a medium of entertainment where the content of the verse has no meaning.

In the learning of the Gita Buana Soedirman Student Choir, the application of lecture methods to explain musical and nonmusical elements occurs about 10-15 minutes. The application of the lecture method is more widely used when in basic education or Pendidikan Dasar (Diksar) which is conducted after the admission's selection of members of the Gita Buana Soedirman Student Choir. At the time of Diksar, the lecture method is more widely used to explain to the new members of the Gita Student Choir Buana Soedirman about what should be learned in choir learning such as basic music theory, choir techniques, and organizational orientation.

2) Demonstration Method

The application of demonstration methods in choir learning in the Gita Buana Soedirman Student Choir is when the coach is explaining to members of the Gita Buana Soedirman Student Choir about vocal techniques. For example, in the learning of the Gita Student Choir Buana Soedirman the coach gave an example of how to form a good soprano sound color. In addition, the application of demonstration methods is also done when explaining how to use song lyrics that use foreign languages or traditional languages. Foreign language songs that have been performed or trained by the Gita Buana Soedirman Student Choir include Wonderful World, A Whole New World, Eternal Flam, and others. The traditional songs that have been performed or trained by the Gita Buana Soedirman Student Choir include Marencongrencong, Sik Sik Sibatumanikam, Paris Barantai, and others.

According to John Pardede, the coach of the Gita Buana Soedirman Student Choir, the application of this demonstration method is often used in demonstrating the pronunciation of foreign language songs such as the example in the song Eternal Flame. In the pronunciation of the song, there are still many members of the Gita Buana Soedirman Student Choir who are wrong in saying the words of the song. For example, in saying the word 'Eternal Flame', many of the members of the Gita Buana Soedirman Student Choir who pronounced the word became 'Eternal Flame', when the supposed pronunciation of the song is 'Iternal Flame'. So, this is where the demonstration method functionates to facilitate members of the Gita Buana Soedirman Student Choir in learning songs.

The method of demonstration in the learning of the Gita Buana Soedirman Student Choir is combined with the lecture method. Based on the explanation of John Pardede, as the coach of Gita Buana Soedirman Student Choir usually, the coach will explain the song material while demonstrating or giving the right example. The demonstration method in the learning of the Gita Buana Soedirman Student Choir lasts about 15-20 minutes.

\section{3) Peer Tutor Method}

The peer tutor method in Gita Buana Soedirman Student Choir learning is applied when the coach is absent then the training will be led by the manager of the Gita Buana Soedirman Student Choir from the field of Gita. In addition, peer tutor methods are also done when learning new songs and exercises will be separated per sound corps. From each sound corps, there are several members who will teach each other in the sound corps.

According to John Pardede, coach of the Gita Buana Soedirman Student Choir, the selection of tutors from each sound corps was directly chosen and trained by him. The member who was chosen to be the leader in the sound corps and officiate to teach other 
members has at least been an active member of the Gita Buana Soedirman Student Choir for 2 years and in terms of skills are already qualified than their juniors. Next, the selected members were trained by John Pardede, the coach of the Gita Buana Soedirman Student Choir in order to become a tutor for their juniors.

The application of peer tutor methods in the learning of Gita Buana Soedirman Student Choir in addition to using tutors in each sound corps, there are also those who are officiated with tutoring, namely Gita Field or coaching field of Gita Buana Soedirman Student Choir. The Gita field itself was also chosen by John Pardede, coach of the Gita Buana Soedirman Student Choir. Gita field itself in the management of the Gita Buana Soedirman Student Choir 2019 consists of 5 people. Where the role of the Gita Field is to lead the course of training when the coach is absent. The members of the Gita Field are officiated with preparing the partiture to be used in the training process, while the Gita Field Chief is tasked with leading the course of choir training to replace the position of choir coach.

According to John Pardede, coach of the Gita Buana Soedirman Student Choir, this peer tutor method is very effective when applied in the learning of the Gita Buana Soedirman Student Choir. This method is said to be effective because in its application it helps speed up song mastery because in practice it is divided per sound corps and per sound corps it has tutors officiated with teaching other members. So, if something goes wrong, it will be quickly overcome and given the correct example by the tutor. In addition, because the age of the tutor is not too far away then in learning the learning atmosphere will be more relaxed and not rigid, so that choir members can understand the song material well. The application of peer tutor methods in the learning of The Gita Buana Soedirman Mahasiwa Choir lasted about 1.5 hours.

4) Imitation Method

In choir learning at UKM Student Choir, coaches use imitation methods when explaining vocal techniques. According to the results of an interview with the coach of UKM Student Choir Gita Buana Soedirman, John Markus Pardede, he explained that in teaching some techniques he experienced difficulties such as when explaining and exemplifying the color of a good and correct soprano sound and then asked the soprano sound group to imitate it.

For some choir groups, perhaps the imitation method is often used when learning a new song and the members have not been fluent in reading the notation so have to listen to the midi of the song and imitate it. However, in the learning of the Gita Buana Soedirman Student Choir, it did not apply because the coach emphasized at the time of Diksar (Basic Education) the new members should be able to read the beam notation themselves. The coach also asked the members of the Gita Buana Soedirman Student Choir to install a virtual piano application on their mobile phones to make it easier to learn songs. So, the members when learning a new song can practice independently per corps of sound without having to scramble in using the piano during practice.

5) Drill Method

The drill method is one of the methods applied in the learning of the Gita Buana Soedirman Student Choir by doing repeated exercises so that the results achieved can be maximized. When going to the competition, the choir coach performs the drill method so that the song material to be performed can be mastered to the maximum. Drill drills are applied during routine training and competition exercises.

According to John Pardede, coach of the Gita Buana Soedirman Student Choir, the drill method is often done when in learning songs and not in accordance with existing song partiture, then the coach will do repetitions. Usually in the process of learning by Gita Buana Soedirman Student Choir, the songs that are often repeated such as Cantate Domino, Seqiovere, Abendlied, and several other German songs. For example, in the song Cantate Domino by Josu Elberdin, in the 48th55th birama for soprano and alto sounds often make mistakes because in the birama there are chromatic tones that cause the part to be trained repeatedly. In that part the repetition is about 10 times or more until the coach feels good then it is not repeated anymore. The duration required for the repetition of the part is approximately 1 hour. 
Based on the results of the above research, the application of the learning method of the Gita Buana Soedirman Student Choir in accordance with the theory of learning methods from Sutikno, that is the learning method is a way of presenting the subject matter conducted by educators in order for the learning process to occur in students in an effort to achieve the goal (Sutikno in Febrianti, 2014). In the learning of the choir at the Gita Buana Soedirman Student Choir, the learning method is used to achieve the goal of being able to master the song along with good and correct vocal techniques. The learning methods used in the Gita Buana Soedirman Student Choir are lecture methods, demonstration methods, imitation methods, and drill methods where they are used continuously and as they should be. The application of choir learning methods in the Gita Buana Soedirman Student Choir is almost the same as the research conducted by Cindy Maya Hernandhes with the title "Golden Choir Training Method trunojoyo Madura University." In her research, the training methods used by the Golden Choir of Trunojoyo Madura University are imitation methods, drill methods, and peer tutor methods. While in the learning of the Gita Buana Soedirman Student Choir, the methods used are lecture methods, demonstration methods, imitation methods, peer tutor methods, and drill methods. According to an interview with Suharto as a choir expert, the learning method is a way to teach the choir to learners about the choir. In the learning of the Gita Buana Soedirman Student Choir, learning methods are used to teach students about vocal techniques in the choir, this is in accordance with the statement of the choir expert.

\section{CONCLUSION}

Based on the results of the research, it can be concluded that in the process of choir learning in the Gita Buana Soedirman Student Choir there are several methods applied, namely lecture methods, demonstration methods, peer tutor methods, imitation methods, and drill methods that are applied continuously and as they should. The lecture method is used as an introduction when rehearsing a song to explain the musical and non-musical elements of a song. Demonstration methods are used to demonstrate vocal techniques or pronunciation methods in some songs that speak foreign languages and traditional languages. Peer tutor methods are performed during training per corps and in each corp there are tutors who will teach other members. In addition, there is also the manager of the Gita Buana Soedirman Student Choir in the Gita field or the field of coaching who is in charge of replacing the coach when the coach is absent. Imitation methods are applied when choir members imitate what the coach teaches, such as examples in vocal technique learning. The drill method is applied when in learning a song, there are errors in certain parts, then the coach will repeat several times the part until it is correct and in accordance with the existing song notation.

\section{REFERENCES}

Akhsin, A. (2013). Pembelajaran Paduan Suara Pada Siswa SD Negeri 1 Sukodadi Lamongan Dengan Metode Mendengarkan. Jurnal Pendidikan Sendratasik, 2(1), 91-100.

Febrianti, Y. N. (2014). Peer Teaching (Tutor Sebaya) Sebagai Metode Pembelajaran Untuk Melatih Siswa Mengajar. Edunomic, 2(2), 87.

Halimah, L. (2016). Musik dalam Pembelajaran. Jurnal Pendidikan Dasar, 3(2), 54-67. http://repositorio.unan.edu.ni/2986 /1/5624.pdf

Juwariyah, C. M. H. A. (2018). Metode Latihan Paduan Suara Golden Universitas Trunojoyo Madua. Jurnal Pendidikan Sendratasik, 6(1), 117.

Linggono, I. B. (2008). Seni Musik Non Klasik. Jakarta: Direktorat Pembinaan Sekolah Menengah Kejuruan. 
Mabry, S. (2003). Exploring twentiethcentury vocal music: a practical guide to innovations in performance and repertoire. Oxford University Press (Vol. 40).

https://doi.org/10.5860/choice.403917

Marchesi, M., \& Miller, P. L. (1970). Bel Canto: A Theoretical \& Practical Vocal Method with a new introduction by. Dover Publications.

Moleong, Lexy. 2007. Metodologi Penelitian Kualitatif. Bandung: Remaja Karya.

Mudjilah, H. S. R. I. (2010). Diktat: Teori Musik 1. Yogyakarta: Universitas Negeri Yogyakarta.

Pamungkas, F. A. (2016). Penerapan Pelatihan Kanon Sebagai Upaya Peningkatan Kepekaan Harmoni Anggota Paduan Suara di SMA NEGERI 1 Rembang. Jurnal Pendidikan Seni Universitas Negeri Yogyakarta, 6(1), 63-68. Retrieved from http://journal.student.uny.ac.id/ojs /ojs/index.php/musik/article/view /9593/9247

Purnomo, I. A. (2013). Bentuk Pertunjukan Gendhit and Friends Pada Pertunjukan Purwokerto Blues Summit Di Purwokerto. Universitas Negeri Semarang.

Purnomo, W., \& Subagyo, F. (2010). Terampil Bermusik. (E. Kusrini, Ed.). Jakarta: Kementerian Pendidikan Nasional.

Sihombing, L. B. (2013). Karakteristik Dan Teknik Bernyanyi Lagu Kategori Negro Spiritual Pada Kelompok Paduan Suara. Jurnal UNIMED, 6(2), 129-143.

Sihombing, L. B. (2017). Manajemen Seni Pertunjukan : Paduan Suara Sebagai
Organisasi Aktualisasi Diri. Jurnal UNIMED, 28(2), 119-130.

Skoog, W. (2004). Developing Vocal Metaphor Technique in singers to visualize images in rehearsals can help them to develop a and. Music Educators Journal, 90(5), 43-48.

Yonathan, H. (2013). Harmoni Modern. Jakarta: Direktorat Pembinaan Sekolah Menengah Kejuruan. 